\title{
Inhibitory Action of Some Essential Oils and Phytochemicals on the Growth of Various Moulds Isolated From Foods
}

\author{
Evandro Leite de Souza ${ }^{1,2 *}$, Edeltrudes de Oliveira Lima ${ }^{3}$, Kristerson Reinaldo de Luna \\ Freire $^{3}$ and Cristina Paiva de Sousa ${ }^{2}$ \\ ${ }^{1}$ Departamento de Nutrição; Universidade Federal da Paraíba; Brazil; ${ }^{2}$ Programa de Pós-graduação em Ciência e \\ Tecnologia de Alimentos; Centro de Tecnologia; Universidade Federal da Paraíba; Brazil; ${ }^{3}$ Departamento de \\ Ciências Farmacêuticas; Universidade Federal da Paraíba; Brazil; evandroleitesouza@bol.com.br; Rua Radialista \\ Antônio Assunção de Jesus, 680/102; Jardim Cidade Universitária; 58052-230; João Pessoa - PA - Brazil
}

\begin{abstract}
The aim of this study was to determine the sensitivity profile of mould strains isolated from foods to some essential oils and phytochemicals. The assayed mould strains were: Fusarium spp., Rhizopus spp., Aspergillus flavus, A. niger and Penicillium spp. According to results, Lippia alba N.E. Brown, Peumus boldus Molina, Lippia microphylla Phil., Citrus limon Risso and Cymbopogon citratus Stapf. essential oil and the phytochemicals citral, eugenol and mircene showed prominent antimould activity. Among the products that evidenced antimould activity, citral and eugenol showed the lowest minimum inhibitory concentrations, which was $1 \%$ and $4 \%$, respectively, for the most of the tested mould strains.
\end{abstract}

Key words: Plant products, antimould activity, sensitivity profile

\section{INTRODUCTION}

Moulds are opportunistic biological agents of ubiquitous nature. They are able to colonize diverse substrates including foods. Because of their powerful arsenal of hydrolytic enzymes, these microorganisms can cause a high degree of deterioration when present in/on foods and can be responsible for considerable economic losses. Furthermore, they can act as potential producer of toxic metabolites, named mycotoxins, which are potentially damaging to consumers health.

It is well established that some plants contain compounds able to inhibit the microbial growth (Naqui et al., 1994). These plant compounds can have different structures and different action when compared with antimicrobials conventionally used to control the microbial growth and survival (Nascimento et al., 2000). The potential antimicrobial properties of plants had been related to their ability to synthesize, by the secondary metabolism, several chemical compounds of relatively complex structures with antimicrobial activity, including alkaloids, flavonoids, isoflavonoids, tannins, cumarins, glycosides, terpens, phenylpropannes, organic acids (Nychas, 1996).

The wide and indiscriminate use of chemical preservatives has been cause of the appearance of over and over resistant microorganisms, leading for occurrence of emerging food borne diseases (Gibbons, 1992; Kaur and Arora, 1999; Akinpelu, 2001). Due to this, there is an increasing interest to obtain alternative antimicrobial agents to use in

\footnotetext{
${ }^{*}$ Author for correspondence
} 
food conservation systems. One of the main procedures used in the research of biologically active substances is the systematic screening of the interaction between microorganisms and plant products. This procedure has been source of useful agents to control the microbial survival in different microbiology application fields (Salvat et al., 2001). Plant products of recognized antimicrobial spectrum could appear in food conservation systems as main antimicrobial compound or as adjuvant to improve the action of other antimicrobial compounds (Kaur and Arora, 1999). The aim of this study was to evaluate the sensitivity profile of moulds strains isolated from foods to some essential oils and phytochemicals with emphasis for a possible future use of the ones as alternative antimould compounds.

\section{MATERIALS AND METHODS}

\section{Essential oils and phytochemicals}

Essential oils evaluated for their antimould spectrum were extracted from Cimbopogom citratus Stapf., Poaceae family; Citrus limon Risso, Rutaceae family, Eucalyptus globulus Labill., Mirtaceae family; Eugenia uniflora L., Mirtaceae family; Lippia alba N.E. Brown, Verbenaceae family; L. microphylla Phil., Verbenaceae family; and Peumus boldus Molina, Lamiaceae family. Phytochemicals evaluated for their antimould spectrum were cariofilene, citral, eucalyptol, eugenol and mircene. Essential oils were provided by the Laboratory of Pharmaceutical Technology, Department of Pharmaceutical Sciences, Federal University of Paraíba, Brazil and the phytochemicals were provided by the Laboratory of Phamacotechnique, Department of Pharmaceutical Sciences, State University of Ponta Grossa, Brazil. These essential oils and phytochemicals were extracted according to standard procedure described by Matos (1994).

\section{Mould strains}

The mould strains were isolated from farinaceous food samples (cassava flour and corn flour) marketed in João Pessoa city, Brazil. The microscopic characteristic observation technique using laminated microculture was used as procedure for mould identification (Lacaz et al., 1991). Aspergillus flavus, A. niger, Fusarium spp., Penicillium spp. and Rhizopus spp. strains were isolated, identified and used as test microorganisms in the antimould assays.

\section{Screening for antimould activity}

Diffusion plate procedure using filter paper discs was used for the screening for antimould activity of essential oils and phytochemicals (Odds, 1989; Hadaceck and Greger, 2000). For this, $1 \mathrm{~mL}$ of mould suspension (approximately $10^{6}$ spores) prepared with sterile $0.85 \%$ physiological saline solution was uniformly spread on the sterile Sabouraud agar Petri dishes. Sterile filter paper discs (Whatman n. 1, diameter $6 \mathrm{~mm}$ ) were soaked with $0.02 \mathrm{~mL}$ of each essential oil or phytochemical and placed on the center of Sabouraud agar Petri dishes inoculated with the mould suspension. The incubation time was 7-10 days at $25^{\circ} \mathrm{C}$. At the end of the incubation period, the inhibition halo diameters were measured using calipers and expressed in millimeters. When the inhibition halo observed was equal or higher than $10 \mathrm{~mm}$ diameter, it was considered as positive antimould activity (Lima et al., 1993).

\section{Determination of the Minimum Inhibitory Concentration (MIC)}

Essential oils and phytochemicals that presented antimould activity in the screening assay were evaluated for their MIC determination and it was carried out by the plate diffusion procedure using wells in dishes (Hadaceck and Greger, 2000). For this, $1 \mathrm{~mL}$ of mould suspension (approximately $10^{6}$ spores) prepared with sterile $0.85 \%$ physiological saline solution was uniformly spread in the sterile Sabouraud agar Petri dishes. After inoculum absorption by Sabouraud agar, wells were made using sterile glass stems (diameter $6 \mathrm{~mm}$ ) which were filled with $50 \mu \mathrm{L}$ of solutions of the essential oil or phytochemical. The different concentration solutions used in the MIC assay were obtained as follow: $0.4 \mathrm{~mL}$ of essential oil or phytochemical and $0.04 \mathrm{~mL}$ of Tween 80 were taken in sterile tubes and the volume was completed to $5 \mathrm{~mL}$ using distilled sterile water. This mixture was shaken for 5 minutes using Vortex and serial dilutions were made to obtain solutions with final concentrations of $8.0,4.0,2.0,1.0$ and $0.5 \%$. The incubation period was $7-10$ days at $25^{\circ} \mathrm{C}$. The concentration able to develop inhibition halos equal or higher than $10 \mathrm{~mm}$ diameter was considered as MIC. Control was carried out with Tween 80 (Lima et al., 1993) by the diffusion technique using filter 
paper discs (Cecon, diameter 6mm) (Bauer and Kirby, 1966).

\section{RESULTS AND DISCUSSION}

Essential oils are volatile substances contained in several plant organs. They play several essential functions for the plant survival including defense against invader microorganisms (Cowan, 1999). Screening results for essential oils antimould activity are shown in Table 1 . From all essential oils evaluated only one (E. uniflora essential oil) did not show any antimould effect. In the screening assay, six essential oils (C. limon, $C$. citratus, E. globulus, L. alba, L. microphylla and $P$. boldus) presented inhibitory action on at least two assayed mould strains. On the other hand, in the MIC determination assay those essential oils did not present any activity to the tested concentration $(8.0,4.0,2.0,1.0$ and $0.5 \%)$ on the mould strains (data not shown). Particularly, only L. alba essential oil was able to exert antimould activity on A. niger up to $4.0 \%$ concentration. Contrary to our results, some researches have shown that this essential oil presented a low antifungal activity and a high antibacterial activity (Lemos et al., 1990; Lima, 1996). C. limom essential oil (Rutaceae family) showed inhibitory activity on A. flavus, Fusarium spp. and A. niger (Table 1). Antimicrobial activity of Rutaceae family species have been observed on dermatophytes (Lima, 1996) and on some moulds (Megalla et al., 1980). C. citratus essential oil showed activity against Rhizopus spp., Fusarium spp. and A. flavus (Table 1). Some moulds as Aspergillus, Cephalosporium, Cladosporium, Curvularia, Fusarium and Rhizopus isolated from stored foods were sensitive to the action of this essential oil (Dubey and Mishra, 1993).

$P$. boldus essential oil was active against $A$. niger, A. flavus and Fusarium spp. In other surveys, this essential oil has shown antimicrobial spectrum when in biological interactions with yeasts (Candida, Tricophyton, Microsporum and Epidermophyton) and bacteria (Staphylococcus aureus, S. epidermidis and Escherichia coli) (Lima, 1996; Farias and Lima, 2000).

The essential oils evaluated in this work have a great variety of phytochemicals that could be considered as responsible for a larger or smaller antimicrobial activity, as follow: i) E-citral, Zcitral, $\alpha$-pinene, geraniole, mircene and $1-\beta$ pinene in C. citratus essential oil; ii) eucalyptol, canfene, mircene, p-methane, terpinen, citral, citronelal in $E$. globulus essential oil; iii) furanodiene, elemene, 2- $\beta$ pinene, terpen, linaleol, cariofilene in $E$. uniflora essential oil; iv) x-elemene, pinene, ciscariofilene, carvacrol, timol and terpineol in $L$. alba essential oil; and v) cineole, terpinene, $\alpha$ pinene, eugenol, cedrol in $P$. boldus essential oil (Craveiro et al., 1981; Lavabre, 1992).

Screening results for antimould activity of the phytochemicals on the moulds strains are shown in Table 2. Cariofilene and eucalyptol did not present any activity on the assayed moulds strains.

Table 1 - Medium values of the inhibition halos $(\mathrm{mm})$ presented in the screening for antimould activity of essential oils on moulds strains isolated from cassava flour and corn flour.

\begin{tabular}{|c|c|c|c|c|c|c|c|c|}
\hline \multirow[b]{2}{*}{ Mould strains } & \multicolumn{7}{|c|}{ Essential oils $^{a}$} & \multirow[b]{2}{*}{ Control $^{b}$} \\
\hline & $\begin{array}{c}C . \\
\text { limon }\end{array}$ & $\begin{array}{c}C . \\
\text { citratus }\end{array}$ & $\begin{array}{c}\text { E. } \\
\text { globulus }\end{array}$ & $\begin{array}{c}E . \\
\text { uniflora }\end{array}$ & L. alba & $\begin{array}{c}L . \\
\text { microphylla }\end{array}$ & P. boldus & \\
\hline Penicillum spp. & 0 & 0 & 0 & 0 & 12 & 0 & 7 & 0 \\
\hline A. niger & 10 & 0 & 12 & 0 & 24 & 24 & 35 & 0 \\
\hline A. flavus & 13 & 10 & 0 & 0 & 0 & 0 & 13 & 0 \\
\hline Fusarium spp. & 0 & 12 & 0 & 0 & 10 & 10 & 10 & 0 \\
\hline Rhizopus spp. & 12 & 13 & 13 & 0 & 12 & 12 & 0 & 0 \\
\hline
\end{tabular}

${ }^{\mathrm{a}}$ absolute concentration; ${ }^{\mathrm{b}}$ control: Tween 80 (absolute concentration)

Citral, eugenol and mircene presented antimould activity and among all citral showed best results. Mircene in all tested concentrations in the MIC assay was not able to inhibit the growth of Fusarium spp. and Rhizopus spp.
MIC of citral and eugenol are shown in Table 3. Citral presented MIC of $0.5 \%$ for A. niger, A. flavus and Fusarium spp., 2.0\% for Penicillium spp. and $8.0 \%$ for Rhizopus spp. Eugenol presented a MIC of $2.0 \%$ for A. flavus and $4.0 \%$ 
for Penicillium spp., Fusarium spp. and Rhizopus spp. A. niger was the single mould strain that presented resistance to eugenol on all tested concentrations.

Phytochemicals are chemical substances characterized as organic biomolecules found and isolated from different plant derivative products, such as teas, decocts, infusions, extracts and essential oils. These compounds are responsible for the biological activities exerted by several plants and their derivative products (Brull and Coote, 1999). Cariofilene, citral, eucalyptol, eugenol and mircene are volatile substances present in several essential oils extracted from plants with recognized antimicrobial properties (Craveiro et al., 1981; Lavabre, 1992; Lima et al., 1993). Thymol, eugenol, anethole, menthol, citral, pinenes, isothiocyanates, cinnamaldheydes, carvacrol, carvone, benzoic acids, fenolic acids, flavones are some phytochemicals that have been studied regarding their antimicrobial spectrum on some bacterial and fungi species (Megalla et al., 1980; Gnamanickman and Mansfield, 1981;
Odebyi et al., 1984; Karapnan, 1990; Delaquis and Mazza, 1995; Helander et al., 1998; Nascimento et al., 2000). In general, the inhibitory action of natural products on mould cells involves cytoplasm granulation, cytoplasmic membrane rupturing and inactivation and/or synthesis inhibition of intercellular and extracellular enzymes. These actions can occur of isolate or concomitant way and culminate with the mycelium germination inhibition (Cowan, 1999).

Occurrence of phytochemicals (Table 2) that did not show antimould activity (cariofilene and eucalyptol), could suggest that probably in some situations certain phytochemicals have their antimicrobial action shown only when acting in synergistic way with other constituents; in other words, when they are in form of extracts, essential oils, decocts, etc. Moreover, resistance and invasion capability of the mould strains used as test microorganisms could be cited as important interfering factors to the antimould efficiency of the essential oils and phytochemicals included in the antimould assays.

Table 2 - Medium values of the inhibition halos $(\mathrm{mm})$ presented in the screening for antimould activity of phytochemicals on moulds strains isolated from cassava and corn flour.

\begin{tabular}{lcccccc}
\hline \multirow{2}{*}{ Mould strains } & \multicolumn{9}{c}{ Phytochemicals $^{*}$} & \multirow{2}{*}{ Control $^{* *}$} \\
\cline { 2 - 5 } & Cariofilene & Citral & Eucalyptol & Eugenol & Mircene & \\
\hline Penicillium spp. & 0 & 37 & 0 & 15 & 0 & 0 \\
A. niger & 0 & 20 & 0 & 0 & 0 & 0 \\
A. flavus & 0 & 30 & 0 & 25 & 0 & 0 \\
Fusarium spp. & 0 & 42 & 0 & 10 & 12 & 0 \\
Rhizopus spp. & 0 & 35 & 0 & 40 & 11 & 0 \\
\hline
\end{tabular}

* absolute concentration; ** Tween 80 (absolute concentration)

Table 3 - MIC values of citral and eugenol on moulds strains isolated from cassava flour and corn flour.

\begin{tabular}{lcc}
\hline \multirow{2}{*}{ Mould strains } & \multicolumn{3}{c}{ Phytochemicals MIC (\%) } \\
\cline { 2 - 3 } & Citral & Eugenol \\
\hline Penicillium spp. & 2.0 & 4.0 \\
A. flavus & 0.5 & 2.0 \\
A. niger & 0.5 & $-*$ \\
Fusarium spp. & 0.5 & 4.0 \\
Rhizopus spp. & 8.0 & 4.0 \\
\hline
\end{tabular}

(-) sensitivity absence to all analyzed concentrations

The results obtained justify future researches emphasizing the antimicrobial properties of plant products and their possible use as viable alternatives to control the microbial growth in foods.

\section{CONCLUSIONS}

According to the results shown we could say that: i) majority of the essential oils and phytochemicals tested showed some "in vitro" inhibitory activity against moulds, having prominence Lippia alba 
essential oil, citral and eugenol; ii) the plant derivative products could be used as alternatives to control microbial contaminants of foods such as moulds, and could be able to become useful tools for application in foods conservation systems.

\section{RESUMO}

O objetivo deste estudo foi determinar o perfil de sensibilidade de cepas de fungos filamentosos isolados de alimento a alguns óleos essenciais e fitoconstituintes. As cepas fúngicas utilizadas nos ensaios antimicrobianos foram: Fusarium spp., Rhizopus spp., Aspergillus flavus, A. niger e Penicillium spp. De acordo com os resultados obtidos, os óleos essenciais de $L$. Alba N.R. Brown, P. boldus Molina, L. microphylla Phill, $C$. limon Risso e C. citratus Stapf. e os fitoconstituintes citral, eugenol e mirceno mostraram destacada atividade antifúngica. Dentre os produtos que apresentaram atividade antifúngica, o citral e eugenol mostraram as menores CIM's, as quais foram $1 \%$ e $4 \%$, respectivamente, para a maioria das cepas fúngicas testadas.

\section{REFERENCES}

Akimpelu, D. A. (2001), Antimicrobial activity of Anacardium occidentale Bark. Fitoterapia, $\mathbf{7 2}$, 286-287.

Bauer, A. W. and Kirby, W. M. M. (1966), Antibiotic susceptibility testing by standardized single disk method. American Journal of Clinical Pathology, 45, 493-496.

Brull, S. and Coote, P. (1999), Preservative agents in foods: mode of action and microbial resistance mechanisms. International Journal of Food Microbiology, 50, 1-17.

Cowan, M. M. (1999), Plants products as antimicrobial agents. Clinical Microbiology Review, 12, 564-582

Craveiro, A. A.; Fernandez, A. G. and Andrade, C. H. S. (1981), Óleos essenciais de plantas do Nordeste. Fortaleza : Editora da UFC.

Delaquis, P. J. and Mazza, G. (1995), Antimicrobial properties of isothiocyanate in food preservation. Food Technology, 49, 73-84.

Dubey, N. K. and Mishra, A. K. (1993), Evaluation of some essentials oils for their toxicity against fungi causing deterioration of stored food commodities. Applied and Environmental Microbiology, 60, 1101-1105.
Farias, N. M. P. and Lima, E. O. (2000), Atividade antifúngica de óleos essenciais obtidos de plantas medicinais contra leveduras do gênero Candida: uma alternativa no controle da infecção hospitalar. Brasília : Prêmio Jovem Cientista. Saúde da População. pp. 91-100.

Gibbons, A. (1992), Exploring new strategies to fight drug resistant microbes. Science, 29, 1036-1038.

Gnanmanickman, S. S. and Mansfield, J. W. (1981), Selective toxicity of wyrone and others phytoalexins to gram-positive bacteria. Phytochemistry, 51, 230-236.

Hadacek, F. and Greger H. (2000), Testing of antifungal natural products: methodologies, comparability of results and essay choose. Phytochemistry Annals, 1, 137-147.

Helander L. M.; Alakomi H. L. and Latva-Kala, K. et al. (1998), Characterization of the action of selected essential oil components on gram-positive bacteria. Journal of Agriculture and Food Chemistry, 46, 3590-3595.

Karapnan, M. (1990), Inhibitory effect of anethole and eugenol on the growth and toxin production of Aspergillus parasiticus. International Journal of Food Microbiology., 10, 193-200.

Kaur, J. and Arora, D. (1999), Antimicrobial activities of species. Int. J. Ant. Agents, 12, 257-262.

Lacaz, C. S.; Porto, E. and Martins, J. E. (1991), Micologia médica. São Paulo: Sarvier.

Lavabre, M. (1992), Aromaterapia: a cura pelos óleos essenciais. Rio de Janeiro.

Lemos, T. L. G.; Matos, F. J. A. and Craveiro, A. A. (1990), Atividade antimicrobiana versus composição química de óleos essenciais. In: Simpósio de plantas medicinais do Brasil, João Pessoa, Paraíba. Anais... João Pessoa. pp. 23.

Lima, E. O. (1996), Estudo das dermatofitoses em João Pessoa-Pb e da atividade de plantas medicinais contra alguns dos fungos isolados. PhD Thesis, University of São Paulo, São Paulo.

Lima, E. O.; Gompertz, O. F.; Giesbrecht, A. M. and Paulo, M. Q. (1993), In vitro antifungal activity of essential oils obtained from officinal plants against dermatophytes. Mycoses, 36, 333-336.

Matos, F. J. A. (1994), Farmácias Vivas. Fortaleza.

Megalla, S. E.; Ross, S. A. and Kektani, N. E. (1980), Antimicrobial activity of some Egyptian aromatic plants. Fitoterapia, 51, 201-206.

Naqui, S. H. A.; Khan, M. S. Y. and Vohora, S. B. (1994), Antibacterial, antifungal and anthelmintic investigation on indian medicinal plants, Fitoterapia, 62, 221-228.

Nascimento, G. G.; Locatelli, J. and Freitas, P. C. (2000), Antibacterial activity of plants extracts and phytochemical on antibiotic resistant bacteria, Brazilian Journal of Microbiology, 31, 247-256. 
Nychas, G. J. E. (1996), Natural antimicrobial from plants. In: Gould, G. W. New methods of food preservation. Londres : CRC Press. pp. 235-258.

Odds, F. C. (1989), Antifungal activity of saperconazole (R.66905) in vitro. Journal of Antimicrobial Chemotherapy, 24, 533-537.

Odebyi, O. O. (1984), Antimicrobial and antifungal properties of the extractives of Jatropha podagrica. Fitoterapia, 56, 135-139.

Salvat, A.; Antonnacci, L.; Fortunato, R. H.; Suarez, E. Y. and Godoy, H. M. (2001), Screening of some plants from Northern Argentine for their antimicrobial activity. Letters in Applied Microbiology, 33, 293-297.

Received: March 24, 2004; Revised: July 19, 2004; Accepted: November 11, 2004 